\title{
Evaluation of antioxidant effect and anticancer activity against human glioblastoma (U373MG) cell lines of Murraya Koenigii
}

\author{
Mrinal Sanaye and Nimisha Pagare \\ Department of Pharmacology, 23 Jote Joy Building, Rambhau Salgaonkar Marg, Cuffe Parade, Colaba, Mumbai: 400005, INDIA.
}

\begin{abstract}
Aim: The main aim of the study was to screen the ethanolic (EEMK) and methanolic (MEMK) extracts of Murraya koenigii (MK) leaves and their alkaloid fractions (EFMK and MFMK) for their in vitro anti-oxidant and anticancer activity against U373MG cell lines. Methods: In vitro antioxidant activity of extracts and fractions was determined by DPPH Radical assay, Reducing power assay, Inhibition of lipid peroxidation, Superoxide radical scavenging assay and Hydroxyl radical scavenging assay. Cytotoxic effect of MK extracts and fractions was evaluated by performing Sulphorhodamine B (SRB) assay and Flow cytometry analysis on U373MG cell lines. Results: Extracts and fractions of MK were found to possess significant antioxidant activity. In SRB colorimetric assay, the efficacy of MK against U373MG cell line was observed due to reduced viability of U373MG cells. Dose dependent significant increase in the percentage of dead cells was also observed. MEMK exhibited significant cytotoxicity than EEMK whereas EFMK and MFMK were not found to be significantly cytotoxic against U373MG cell lines. Flow cytometry analysis revealed that the effective
\end{abstract}

extract MEMK induces cell death in human glioblastoma cells through apoptotic mode of action. Conclusion: The observed anticancer activity of Murraya koenigii may be due to its antioxidant potential.

Key words: Murraya koenigii, Antioxidant, Anticancer, Glioblastoma, SRB assay, Flow cytometry.

Correspondence :

Dr. Mrinal Sanaye, Department of Pharmacology,

Address:23, Jote Joy Building,

Rambhau Salgaonkar Marg, Cuffe Parade,Colaba,

Mumbai-400005, INDIA.

Ph no: 9820270269

Email: mrinalsanaye25@gmail.com

DOI : 10.5530/pj.2016.3.7

\section{INTRODUCTION}

Oxidative Stress is involved in the process of development of cancer and tumors. ROS formed due to oxidative stress can damage the macromolecules such as lipids, which react with metals (such as free iron and copper) and produce aldehydes such as malondialdehyde. This can induce mutations or cause breaks in the double chain, produce modifications in guanine and thymine bases, and sister chromatid exchanges, which can affect the activities of signal transduction, transcription factors, and gene tumor suppressors such as $p 53$, playing an important role in apoptosis and in cell cycle control. ${ }^{1}$ Chemotherapy as well as radiotherapy for cancer treatment is associated with induction of oxidative stress leading to apoptosis which results in severe side effects. This arises a need for utilizing antioxidant potential of phytochemicals of plant origin for effective management of cancer.

Murraya koenigii Linn (Rutaceae) commonly known as curry leaf, is an aromatic more or less deciduous shrub tree commonly used in Indian diet. $^{2}$ Leaves contain alkaloids such as girinimbin, iso-mahanimbin, koenine, koenigine, koenidine and koenimbine, Mahanimbicine and bicyclomahanimbicine. ${ }^{3,45}$ Leaves are reported to possess antioxidant, antibacterial, antifungal, larvicidal, anticarcinogenic, hypoglycemic, hypolipidemic and antihypertensive activity. ${ }^{6}$ The carbazole alkaloids mahanine, pyrafoline-D and murrafoline-I have reported to possess significant cytotoxicity against HL-60 cells and induce the loss of mitochondrial membrane potential ${ }^{7}$ Mahanine, isolated from the leaves of $M$. koenigii, has found to have a dose- and time-dependent antiproliferative activity in acute lymphoid (MOLT-3) and chronic myeloid (K562) leukemic cell lines and in the primary cells of leukemic and myeloid patients, with minimal effect on normal immune cells. ${ }^{8}$ The in-vitro anti-tumour activity and antioxidant properties of Girinimbine isolated from the stem bark of Murraya koenigii was studied by Yih et al. ${ }^{9}$
Glioblastoma multifome is the most common and deadliest of malignant primary brain tumor in adults and is one of a group of tumors referred to as gliomas. The treatment for glioblastoma mainly includes surgery with radiotherapy and chemotherapy options are rarely available. Therefore, in the present study we have analyzed extracts and alkaloid fractions of Murraya koenigii leaves for their in vitro antioxidant and anticancer activity against glioblastoma U373MG cell lines.

\section{MATERIAL AND METHODS}

\section{Chemicals}

1, 1-diphenyl-2-picryl-hydrazyl (DPPH), Potassium ferricyanide $\left(\left[\mathrm{K}_{3} \mathrm{FE}(\mathrm{CN})_{6}\right]\right)$, Trichloroacetic acid (TCA), Ferric chloride $\left(\mathrm{FeCl}_{3}\right)$, Sodium dodecyl sulphate (SDS), Thiobarbituric acid (TBA), Nitoblue tetrazolium (NBT), Nicotinamine adenine dinucleotide (NADH), Phenazine methosulphate (PMS), Ethylene diamine tetraacetic acid (EDTA), Hydrogen peroxide $\left(\mathrm{H}_{2} \mathrm{O}_{2}\right)$ were purchased from Loba chemicals.

\section{Plant material}

Leaves of Murraya koenigii (MK) were collected from Kurla market, Mumbai. The plant (specimen\#: np140104) was authenticated at Guru Nanak Khalsa College, Department of Botany, Mumbai.

\section{Preparation of plant extracts and fractions}

Fresh leaves were air dried, powdered mechanically and passed through 40\#. Powdered plant material was extracted in a Soxhlet apparatus using $90 \%(\mathrm{v} / \mathrm{v})$ ethanol and $100 \%$ methanol as solvents to obtain ethanolic extract (EEMK) and methanolic extract (MEMK) respectively. Distillate obtained was heated on a water bath to obtain a dry semisolid paste. Alkaloid fractions were separated from extracts. ${ }^{10}$ The dry extracts and their fractions were stored in air-tight containers at $2-4^{\circ} \mathrm{c}$ for further experimental use. 


\section{In vitro antioxidant assay}

\section{DPPH assay}

The scavenging activity was determined by DPPH assay previously reported by Blois (2009). $7.9 \mathrm{mg}$ of DPPH was accurately weighed and dissolved in $100 \mathrm{ml}$ methanol to obtain $200 \mu \mathrm{M}$ solution of $\mathrm{DPPH}$. Aliquots of different concentrations of extracts $(10 \mu \mathrm{g} / \mathrm{ml}, 20 \mu \mathrm{g} / \mathrm{ml}, 30 \mu \mathrm{g} /$ $\mathrm{ml}, 40 \mu \mathrm{g} / \mathrm{ml}, 50 \mu \mathrm{g} / \mathrm{ml})$ and fractions $(5 \mu \mathrm{g} / \mathrm{ml}, 10 \mu \mathrm{g} / \mathrm{ml}, 50 \mu \mathrm{g} / \mathrm{ml}, 100$ $\mu \mathrm{g} / \mathrm{ml}, 150 \mu \mathrm{g} / \mathrm{ml}, 200 \mu \mathrm{g} / \mathrm{ml})$ were added to $1 \mathrm{ml}$ of DPPH solution. After incubating test tubes for $30 \mathrm{~min}$ in dark, absorbance was measured at 517 nm against blank. ${ }^{11}$ Extracts and fractions were compared with standard Quercetin. The radical scavenging activity was calculated from the equation:-

$\%$ radical scavenging activity $=\frac{(\text { Abs control-Abs sample })}{\text { Abs control }} \times 100$

Abs-Absorbance.

\section{Reducing power assay}

Reducing power was determined by previously reported method Oyaizu (1986) The different concentrations of extracts $(5 \mu \mathrm{g} / \mathrm{ml}, 10 \mu \mathrm{g} / \mathrm{ml}$, $20 \mu \mathrm{g} / \mathrm{ml}, 30 \mu \mathrm{g} / \mathrm{ml}, 40 \mu \mathrm{g} / \mathrm{ml})$ and fractions $(5 \mu \mathrm{g} / \mathrm{ml}, 10 \mu \mathrm{g} / \mathrm{ml}, 50 \mu \mathrm{g} / \mathrm{ml}$, $100 \mu \mathrm{g} / \mathrm{ml}, 150 \mu \mathrm{g} / \mathrm{ml}, 200 \mu \mathrm{g} / \mathrm{ml}$ ) were mixed with $2.5 \mathrm{ml}$ phosphate buffer $(0.2 \mathrm{M}, \mathrm{pH} 6.6)$ and $2.5 \mathrm{ml} \mathrm{K}_{3}\left[\mathrm{FE}(\mathrm{CN})_{6}\right](1 \%)$. The reaction mixture was incubated at $50^{\circ} \mathrm{C}$ for $20 \mathrm{~min}$. After incubation, $2.5 \mathrm{ml}$ of TCA (10\%) was added and centrifuged at $7000 \mathrm{rpm}$. for $10 \mathrm{~min} .2 .5 \mathrm{ml}$ solution from the upper layer was mixed with $2.5 \mathrm{ml}$ distilled water and freshly prepared $0.5 \mathrm{ml} \mathrm{FeCl}_{3}(0.1 \%){ }^{12}$ Extracts and fractions were compared with standard Quercetin. Higher absorbance of the reaction mixture indicated greater reducing power.

\section{Inhibition of Lipid peroxidation}

Freshly excised rat brain was processed to get $10 \%$ homogenate in cold phosphate buffer, pH7.4 Degree of lipid peroxidation was assayed by estimating the TBARS formed. The reaction mixture contains $0.1 \mathrm{ml}$ of different concentrations of extracts $(10 \mu \mathrm{g} / \mathrm{ml}, 20 \mu \mathrm{g} / \mathrm{ml}, 30 \mu \mathrm{g} / \mathrm{ml}, 40$ $\mu \mathrm{g} / \mathrm{ml}, 50 \mu \mathrm{g} / \mathrm{ml})$ and fractions $(5 \mu \mathrm{g} / \mathrm{ml}, 10 \mu \mathrm{g} / \mathrm{ml}, 50 \mu \mathrm{g} / \mathrm{ml}, 100 \mu \mathrm{g} / \mathrm{ml}$, $150 \mu \mathrm{g} / \mathrm{ml}, 200 \mu \mathrm{g} / \mathrm{ml}$ ) were added to the brain homogenate. $0.2 \mathrm{ml}$ SDS (8.1\%), $1.5 \mathrm{ml}$ of acetic acid (20\%) solution and $1.5 \mathrm{ml}$ of aqueous solution of TBA $(0.8 \%)$ were added to the homogenate mixture The mixture was finally made up to $4.0 \mathrm{ml}$ with distilled water, and heated at $95^{\circ} \mathrm{C}$ for $60 \mathrm{~min}$. After cooling with tap water, $1.0 \mathrm{ml}$ of distilled water and $5.0 \mathrm{ml}$ of mixture of $\mathrm{n}$-butanol and pyridine (5:1) were added, and the mixture was shaken vigorously. After centrifugation at $4000 \mathrm{rpm}$ for $10 \mathrm{~min}$, the absorbance of the organic layer (upper layer) was measured at $532 \mathrm{~nm} .^{13}$

The radical scavenging activity was calculated from the equation:-

$\%$ radical scavenging activity $=\frac{(\text { Abs control-Abs sample })}{\text { Abs control }} \times 100$

\section{Superoxide scavenging assay}

The method described by Liu et al (1997) was used for determination of superoxide anion scavenging activity of extracts and fractions. Superoxide radicals were generated in $3 \mathrm{ml}$ of Tris- $\mathrm{HCl}$ buffer $(16 \mathrm{mM}$, $\mathrm{pH}$ 8) containing NBT (50 mM) solution and $1 \mathrm{ml}$ of NADH $(78 \mathrm{mM})$ solution and $1 \mathrm{ml}$ of sample solutions of extracts and fractions at different concentrations. Reaction was initiated by adding $1 \mathrm{ml}$ PMS solution $(10 \mu \mathrm{M}$, ) to the mixture. The reaction mixture was incubated at $25^{\circ} \mathrm{C}$ for $5 \mathrm{~min}$, and the absorbance was read at $560 \mathrm{~nm}$ by UV-visible spectrophotometer. Decreased absorbance of the reaction mixture indicated increased superoxide anion scavenging activity. ${ }^{14}$ The percentage inhibition of superoxide anion generation was calculated using the following formula:

$\%$ radical scavenging activity $=\frac{(\text { Abs control }- \text { Abs sample })}{\text { Abs control }} \times 100$

Abs-Absorbance.

\section{Hydroxyl radical scavenging assay}

Deoxyribose method of Halliwell et al (1987) was used to determine the hydroxyl radical scavenging activity. The reaction mixture, which contained different concentrations of extracts and fractions, deoxyribose (3.75 mM), $\mathrm{H}_{2} \mathrm{O}_{2}(1 \mathrm{mM})$, potassium phosphate buffer ( $\left.20 \mathrm{mM}, \mathrm{pH} 7.4\right)$, $\mathrm{FeCl}_{3}(0.1 \mathrm{mM})$, EDTA $(0.1 \mathrm{mM})$ and ascorbic acid $(0.1 \mathrm{mM})$, was incubated in a water bath at $(37 \pm 0.5)^{\circ} \mathrm{C}$ for $1 \mathrm{hr}$. $1 \mathrm{~mL}$ of TBA $(1 \% \mathrm{w} /$ $\mathrm{v})$ and $1 \mathrm{ml}$ of TCA $(2.8 \% \mathrm{w} / \mathrm{v})$ were added to the mixture and heated in a water bath at $100^{\circ} \mathrm{C}$ for $20 \mathrm{~min}$ The mixture was then incubated at $37^{\circ} \mathrm{C}$ for $1 \mathrm{~h}$. After incubation, $1 \mathrm{ml}$ of the incubated mixture was mixed with $1 \mathrm{ml}$ of $10 \%$ TCA and $1 \mathrm{ml}$ of $0.5 \%$ TBA to develop the chromogen, measured at $532 \mathrm{~nm} .{ }^{15}$ The radical scavenging activity was calculated from the equation:-

$\%$ radical scavenging activity $=\frac{(\text { Abs control }- \text { Abs sample })}{\text { Abs control }} \times 100$

Abs-Absorbance.

\section{In vitro cytotoxicity evaluation}

\section{Cell culture and experiment design}

The cell lines (U373MG) of glioblastoma human tissue origin) were grown in RPMI 1640 medium containing 10\% fetal bovine serum and $2 \mathrm{mM}$ L-glutamine. For present screening experiment, cells were inoculated into 96 well microtiter plates in $100 \mu \mathrm{l}$. After cell inoculation, the microtiter plates were incubated at $37^{\circ} \mathrm{C}, 5 \% \mathrm{CO}_{2}, 95 \%$ air and $100 \%$ relative humidity for $24 \mathrm{~h}$ prior to addition of experimental drugs. Extracts EEMK, MEMK, alkaloid fractions EFMK, MFMK and standard Adriamycin (ADR) were initially solubilized in dimethyl sulfoxide (DMSO) at $100 \mathrm{mg} / \mathrm{ml}$ and diluted to $1 \mathrm{mg} / \mathrm{ml}$ using water and stored frozen prior to use. At the time of drug addition, an aliquot of frozen concentrate $(1 \mathrm{mg} / \mathrm{ml})$ was thawed and diluted to $100 \mu \mathrm{g} / \mathrm{ml}, 200 \mu \mathrm{g} / \mathrm{ml}$, $400 \mu \mathrm{g} / \mathrm{ml}$ and $800 \mu \mathrm{g} / \mathrm{ml}$ with DMSO. Aliquots of $10 \mu \mathrm{l}$ of these different drug dilutions were added to the appropriate micro titer wells already containing $90 \mu \mathrm{l}$ of medium, resulting in the required final drug concentrations i.e. $10 \mu \mathrm{g} / \mathrm{ml}, 20 \mu \mathrm{g} / \mathrm{ml}, 40 \mu \mathrm{g} / \mathrm{ml}, 80 \mu \mathrm{g} / \mathrm{ml}^{16}$

\section{Sulphorhodamine B assay}

Sulforhodamine B (SRB) assay was developed by Skehan and colleagues to measure drug-induced cytotoxicity and cell proliferation for largescale drug-screening applications. Its principle is based on the ability of the protein dye sulforhodamine $\mathrm{B}$ to bind electrostatically and $\mathrm{pH}$ dependent on protein basic amino acid residues of trichloroacetic acidfixed cells. Under mild acidic conditions it binds to and under mild basic conditions it can be extracted from cells and solubilized for measurement. After incubation for $48 \mathrm{~h}$ assay was terminated by the addition of cold TCA. Cells were fixed in situ by the gentle addition of $50 \mu \mathrm{l}$ of cold $30 \%(\mathrm{w} / \mathrm{v})$ TCA and incubated for $60 \mathrm{~min}$ at $4^{\circ} \mathrm{C}$. The supernatant was discarded; the plates were washed five times with tap water and air dried. Sulforhodamine B (SRB) solution $(50 \mu \mathrm{l})$ at $0.4 \%(\mathrm{w} / \mathrm{v})$ in $1 \%$ acetic acid was added to each of the wells, and plates were incubated for $20 \mathrm{~min}$ at room temperature. After staining, unbound dye was recovered and the residual dye was removed by washing five times with $1 \%$ acetic acid. The plates were air dried. Bound stain was subsequently eluted with $10 \mathrm{~m}$ Mtrizma base, and the absorbance was read on a plate reader at a wavelength of $540 \mathrm{~nm}$ with $690 \mathrm{~nm}$ reference wavelength. ${ }^{16}$ 


\section{Cell cycle analysis}

The cell cycle analysis by Flow cytometry is the primary method of choice, which allows measuring of drug potency, selectivity and mechanism of action. Fluorescent dye such as Propidium iodide intercalates between the double stranded nucleic acid to produce red fluorescence. It also binds to double stranded RNA so as to be removed by RNAse. It is important that the cells must be fixed or permeabilised to allow access of the dye because it is not able to penetrate an intact membrane. This dye can be used to determine quantity of cellular DNA and also distribution of cell cycle in population of interest.

U373MG cells were plated at a density of $1.5 \times 10^{6}$ cells in a $10 \mathrm{~cm}$ dish. Next day, cells were treated with different doses of extracts. After $24 \mathrm{~h}$ incubation, cells were harvested and suspended in 1X-PBS containing $2 \%$ FBS. The cells were fixed with $70 \%$ ethanol at $4^{\circ} \mathrm{C}$ for $1 \mathrm{~h}$ followed by the addition of propidium iodide $(5 \mu \mathrm{g} / \mu \mathrm{l})$ and RNase $(10 \mu \mathrm{g} / \mu \mathrm{l})$ and further incubated for $3 \mathrm{~h}$ at $4^{\circ} \mathrm{C}$. The DNA content was evaluated in a flow cytometer ${ }^{17}$ (BD FACS Calibur, USA). The data was analyzed using Modfit software (BD, Biosciences, USA)

\section{RESULTS}

\section{DPPH assay}

EEMK, MEMK, EFMK and MFMK showed promising free radical scavenging effect on DPPH radical in a concentration dependent manner. The $\mathrm{IC}_{50}$ values of EEMK and MEMK were found to be $10.54 \mu \mathrm{g} / \mathrm{ml}$ and $69.89 \mu \mathrm{g} / \mathrm{ml}$ respectively (Figure 1 ). The $\mathrm{IC}_{50}$ values of EFMK and MFMK were found to be $65.05 \mu \mathrm{g} / \mathrm{ml}$ and $63.00 \mu \mathrm{g} / \mathrm{ml}$ respectively (Figure 2). The extracts were compared with standard Quercetin having $\mathrm{IC}_{50}$ value of $17.42 \mu \mathrm{g} / \mathrm{ml}$

\section{Reducing power assay-}

Reducing power of MEMK was found to be higher than EEMK at $10 \mu \mathrm{g} / \mathrm{ml}$, $20 \mu \mathrm{g} / \mathrm{ml}, 30 \mu \mathrm{g} / \mathrm{ml}, 40 \mu \mathrm{g} / \mathrm{ml}, 50 \mu \mathrm{g} / \mathrm{ml}$ (Figure 3) whereas reducing power of EFMK was found to be higher than MFMK at, $10 \mu \mathrm{g} / \mathrm{ml}$, $50 \mu \mathrm{g} / \mathrm{ml}, 100 \mu \mathrm{g} / \mathrm{ml}, 150 \mu \mathrm{g} / \mathrm{ml}, 200 \mu \mathrm{g} / \mathrm{ml}$ (Figure 4). Both the extracts and fractions were compared with the reducing power of standard Quercetin.

\section{Inhibition of Lipid peroxidation assay}

EEMK, MEMK, EFMK and MFMK elicited concentration dependent inhibition of $\mathrm{FeSO} 4$ induced lipid peroxidation in rat brain homogenate. The $\mathrm{IC}_{50}$ values of EEMK and MEMK were found to be $29.8 \mu \mathrm{g} / \mathrm{ml}$ and $33.9 \mu \mathrm{g} / \mathrm{ml}$ respectively (Figure 5 ). The $\mathrm{IC}_{50}$ values of EFMK and MFMK were found to be $84.7 \mu \mathrm{g} / \mathrm{ml}$ and $67.4 \mu \mathrm{g} / \mathrm{ml}$ respectively (Figure 6). IC value of Quercetin was found to be $60.07 \mu \mathrm{g} / \mathrm{ml}$

\section{Superoxide scavenging assay}

EEMK, MEMK, EFMK and MFMK showed free radical scavenging effect on superoxide radical in a concentration dependent manner. The $\mathrm{IC}_{50}$ values of EEMK and MEMK were found to be $13.5 \mu \mathrm{g} / \mathrm{ml}$ and $9.33 \mu \mathrm{g} / \mathrm{ml}$ respectively (Figure 7). The $\mathrm{IC}_{50}$ values of EFMK and MFMK were found to be $31.91 \mu \mathrm{g} / \mathrm{ml}$ and $22.62 \mu \mathrm{g} / \mathrm{ml}$ respectively (Figure 8). The extracts and fractions were compared with standard Ascorbic acid having $\mathrm{IC}_{50}$ value of $4.87 \mu \mathrm{g} / \mathrm{ml}$.

\section{Hydroxyl scavenging assay}

The $\mathrm{IC}_{50}$ values of EEMK and MEMK were found to be $10.9 \mu \mathrm{g} / \mathrm{ml}$ and $45.2 \mu \mathrm{g} / \mathrm{ml}$ respectively (Figure 9 ). The $\mathrm{IC}_{50}$ values of EFMK and MFMK were found to be $96.1 \mu \mathrm{g} / \mathrm{ml}$ and $75.5 \mu \mathrm{g} / \mathrm{ml}$ respectively (Figure 10) The extracts and fractions were compared with standard Ascorbic acid having $\mathrm{IC}_{50}$ value of $4.7 \mu \mathrm{g} / \mathrm{ml}$.

\section{Sulphorhodamine B assay}

TThe $\mathrm{GI}_{50}$ value of MEMK and EEMK was found to be $15 \mu \mathrm{g} / \mathrm{ml}$ and 26.7 $\mu \mathrm{g} / \mathrm{ml}$ respectively when compared with standard anticancer drug ADR

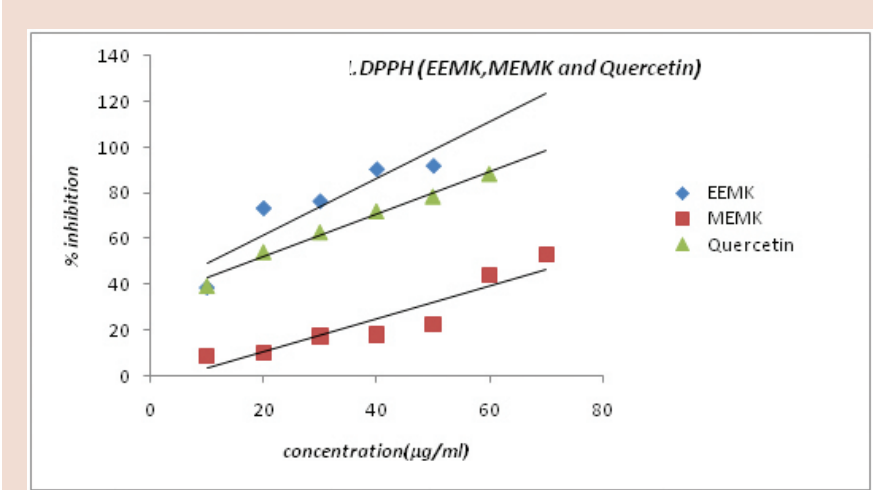

Figure 1: DPPH scavenging assay of extracts and standard.

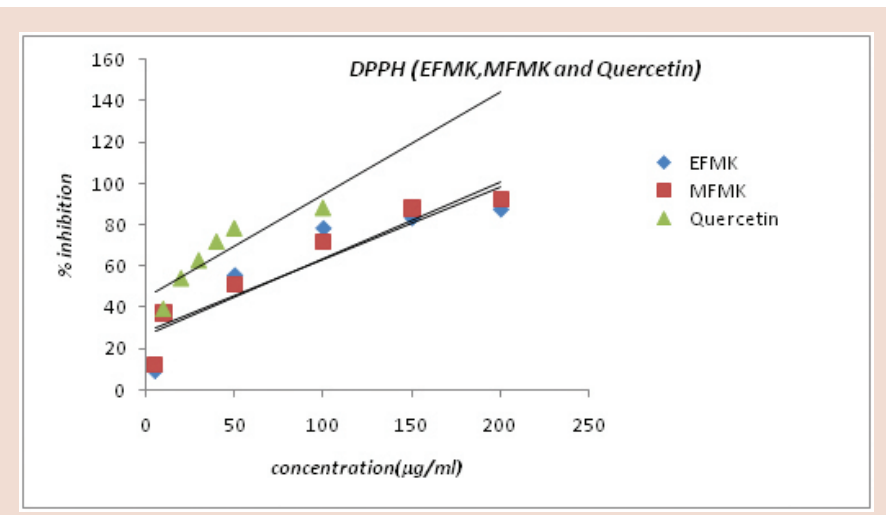

Figure 2: DPPH scavenging assay of fractions and standard.

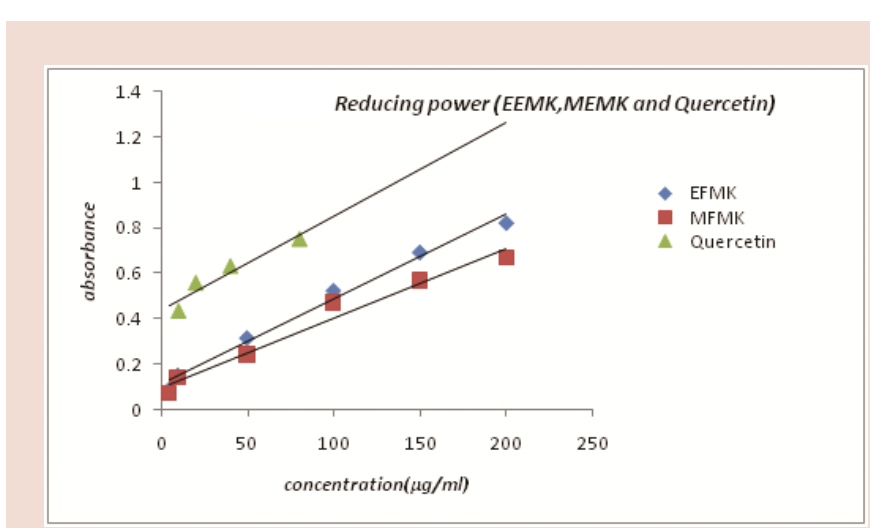

Figure 3: Reducing power of extracts and standard.

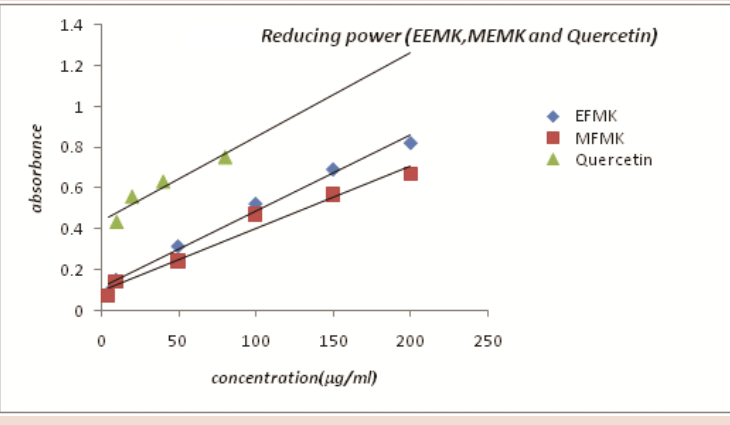

Figure 4: Reducing power of fractions and standard. 


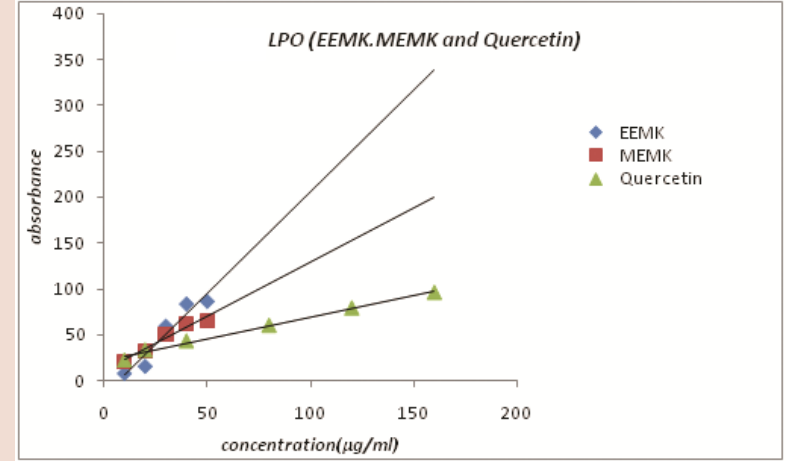

Figure 5: Inhibition of lipid peroxidation of extracts and standard.

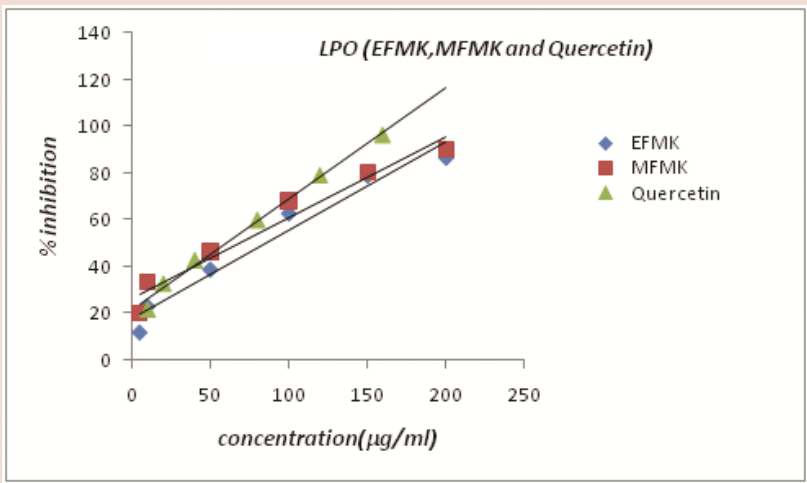

Figure 6: Inhibition of lipid peroxidation of fractions and standard.

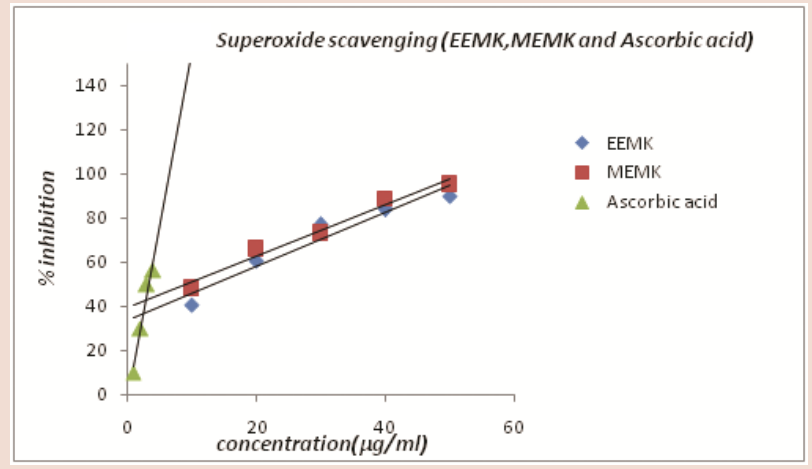

Figure 7: Superoxide radical scavenging assay of extracts and standard.

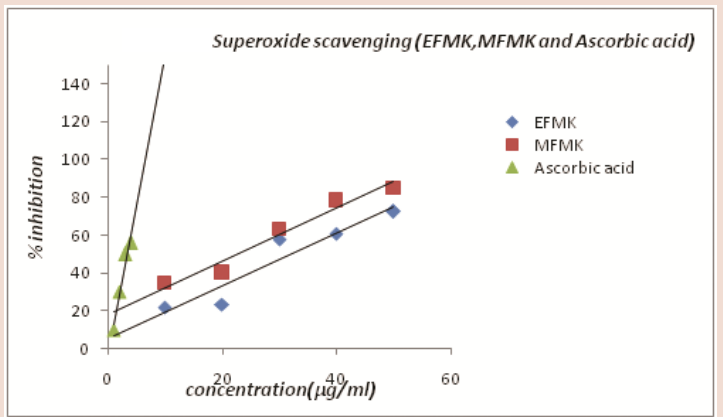

Figure 8: Superoxide radical scavenging assay of fractions and standard.

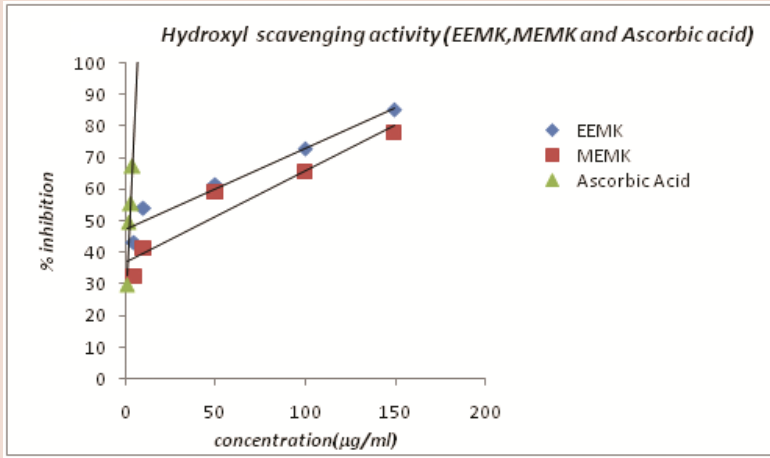

Figure 9: Hydroxyl radical scavenging assay of extracts and standard.

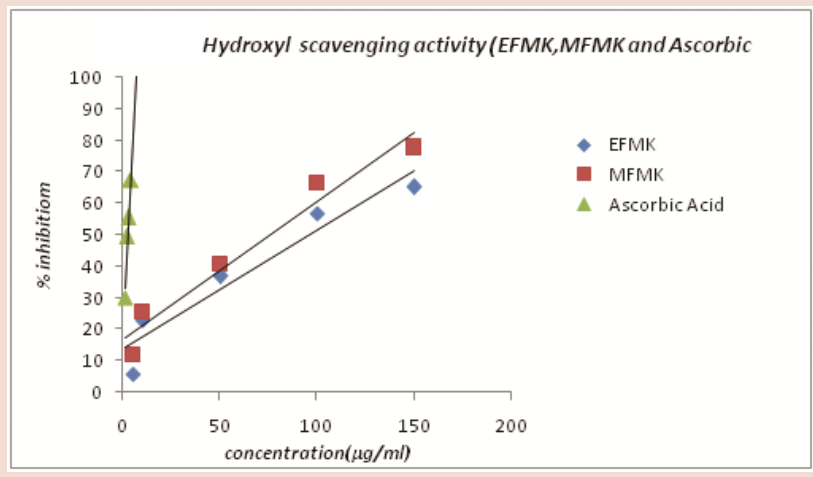

Figure 10: Hydroxyl radical scavenging assay of fractions and standard.

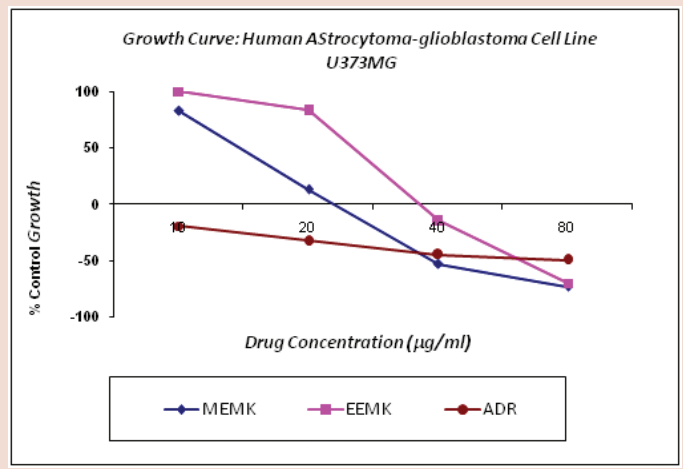

Figure 11: Growth curve of extracts and standard against U373MG cell line.

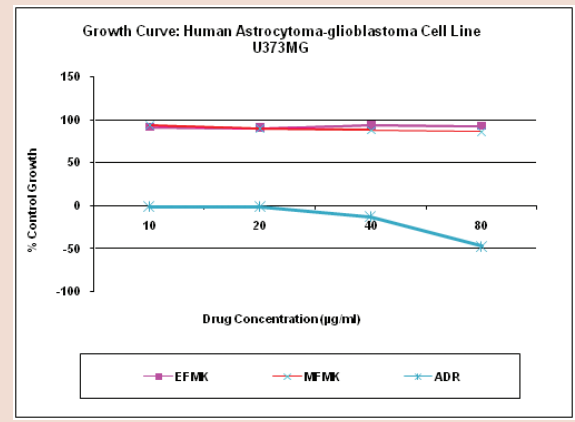

Figure12: Growth curve of fractions and standard against U373MG cell line. 


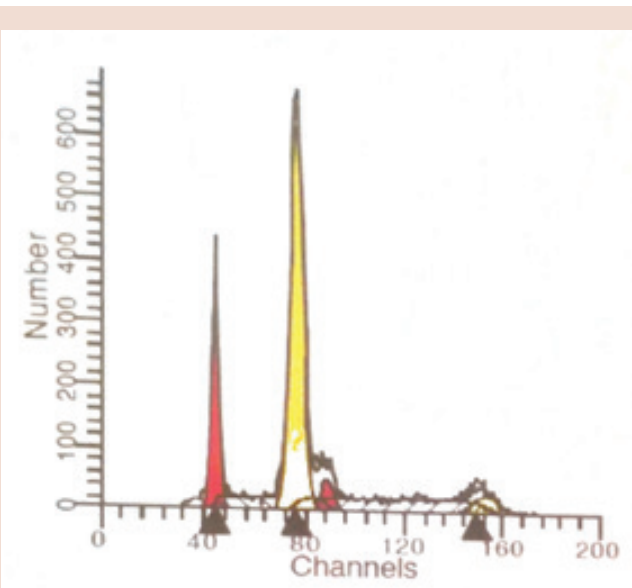

A. Analysis of cell cycle of tumor cells before treatment with extracts

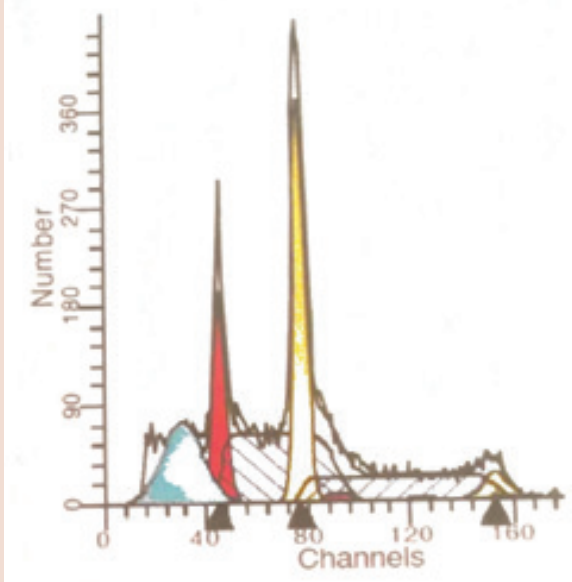

B. Analysis of cells after treatment with MEMK

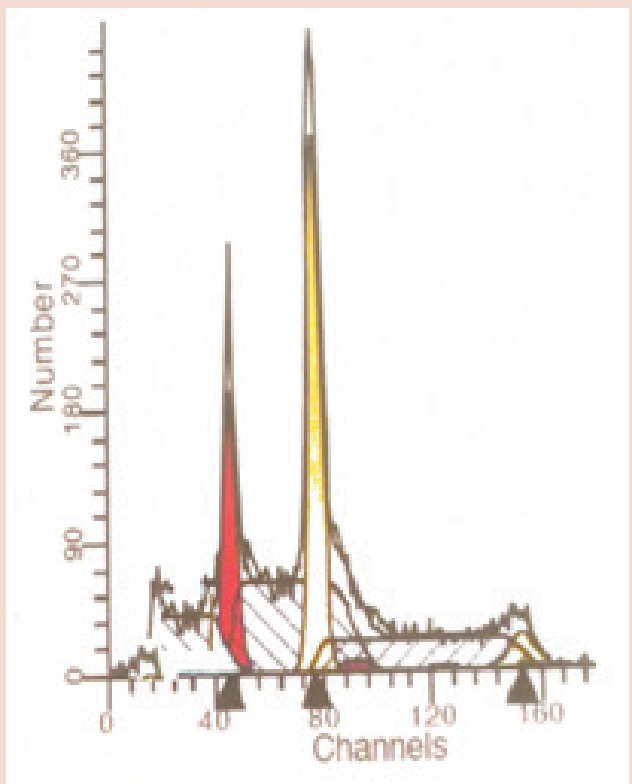

C. Analysis of cells after treatment with EEMK

Figure 13: Figure depicting cell cycle analysis of tumor cells before and after treatment with EEMK and MEMK. having $\mathrm{GI}_{50}$ value of less than $10 \mu \mathrm{g} / \mathrm{ml}$ (Figure 11). EFMK and MFMK did not show any significant cytotoxic activity (Figure 13b). These results indicate that MEMK extract was found to be more potent than EEMK showing less $\mathrm{GI}_{50}$ value (Figure 12). Fractions EFMK and MFMK did not inhibit the cell growth in cytotoxicity assay.

\section{Cell cycle analysis}

Analysis of DNA cell cycle before treatment of EEMK and MEMK shows two different types of cell cycles i.e. diploid and aneuploid cells. (Figure 13a) Diploid cell cycle was found to be $30.47 \%$ of total cell population. Large peak corresponds to G0/G1 phase (red color) with $48.42 \%$ cells. Small peak corresponds to G2/M phase (red color) with $13.36 \%$ cells. Line represents S phase with $38.22 \%$ cells Aneuploid cell cycle was found to be $69.53 \%$ of total cell population. Largest peak corresponds to G0/G1 phase (yellow color) with $66.67 \%$ cells. Small peak corresponds to G2/M phase (yellow color) with $8.06 \%$ cells. Lined area represents S phase with $25.27 \%$ cells. Analysis of DNA cell cycle after treatment with MEMK: shows presence of apoptotic cells (Figure 13b) along with diploid and aneuploid cells. Diploid cell cycle comprises of $49.44 \%$ of total cell population. Large peak G0/G1 phase (red color) corresponds to $28.17 \%$ cells. Small peak represents G2/M phase (red color) with $2.15 \%$ cells Lined area represents S phase with $69.68 \%$ cells. Aneuploid cell cycle consists of $50.56 \%$ of total cell population. Largest peak represents G0/G1 phase (yellow color) with $53.16 \%$ cells. Small peak represents G2/M phase (yellow color) with $6.73 \%$ cells. Lined area represents S phase with $40.11 \%$ cells. Blue color peak indicates apoptotic cells with $14.68 \%$ After treatment with EEMK, no significant change in the number of cells found in Diploid and Aneuploid cell cycle was observed when compared with DNA cell cycle analysis before treatment (Figure 13c). These results indicate that MEMK showed induction of apoptosis cells whereas EEMK was not found to induce apoptosis in glioblastoma cell lines.

\section{DISCUSSION}

In the present study, the antioxidant potential of EEMK, MEMK, EFMK and MFMK was evaluated with the help of in-vitro antioxidant models like DPPH free radical scavenging activity, Reducing power assay and Lipid peroxidation, Superoxide radical scavenging activity and Hydroxyl radical scavenging activity.

Free radical scavenging activity of the extracts and fractions was evaluated based on their ability to scavenge DPPH. Bleaching of DPPH absorption is a representative of the capacity of the test drug to scavenge free radicals independently. Here, EEMK, MEMK, EFMK and MFMK presented good scavenging of DPPH free radical which might be due to their ability to transfer electrons to the DPPH radical thereby showing reduction in absorbance.

In reducing power assay, the antioxidants in extracts and fractions brought about reduction of $\mathrm{Fe}^{3+}$ to $\mathrm{Fe}^{2+}$. The amount of $\mathrm{Fe}^{2+}$ formed was monitored by measuring the formation of Perl's Prussian blue at $700 \mathrm{~nm}$. Increasing absorbance indicated an increase in the reducing power of extracts and fractions.

In the current method effectiveness of EEMK, MEMK, EFMK and MFMK is evaluated as inbition of lipid peroxidation. Extracts and fractions reduced the initiating perferryl radical with the formation of ubisemiquinone and $\mathrm{H}_{2} \mathrm{O}_{2}$. Additionally, it is possible that they might have also eliminated lipid peroxyl radicals. Extracts EEMK and MEMK were found to be exerting more potent antioxidant effect in preventing lipid peroxidation than standard Quercetin.

Extracts and fractions exhibited a dose dependent increase in superoxide scavenging activity. MEMK showed stronger superoxide radical scavenging activity than EEMK The fractions exhibited poor scavenging activity as compared to extracts EEMK, MEMK and standard Ascorbic 
acid. In hydroxyl radical scavenging assay extracts were found to be more potent than fractions in scavenging hydroxyl radicals. Thus, all these observations indicate that extracts exhibit more antioxidant potential than fractions. Among all the assays, it was found that extracts showed significant antioxidant activity against lipid peroxides formed in brain tissue. As brain tissue is rich with lipid content, extracts carry a promising potential to prevent oxidative stress induced complications during cancer therapy of glioblastoma.

During evaluation of anticancer activity, in SRB assay, more significant increase in the percentage of dead cells in U373MG glioblastoma cell lines were observed after treatment with MEMK as compared to treatment with EEMK and fractions EFMK and MFMK, suggesting cytotoxic activity of MEMK.

In Flow cytometry analysis, apoptotic cells were found to be present after treatment with MEMK which were not observed on treatment with EEMK and fractions EFMK and MFMK. Thus, flow cytometry analysis further confirmed that the observed cytotoxic effect of MEMK was due to apoptotic mode of action.

We found that the methanolic extract of curry leaves significantly decreased cell growth in human glioblastoma cell lines in a dose-dependent manner whereas alkaloid fractions of the ethanolic and methanolic extract of Murraya koenigii were not found to exhibit significant anticancer effect on glioblastoma cell lines.

In conclusion, Murraya koenigii plant extracts and fractions have potent antioxidant activity which might be useful in preventing oxidative stress during cancer treatment. Among both the extracts and fractions, MEMK has ability to produce significant death of U373MG cells whereas its alkaloid fraction has failed to show cytotoxic effect. Hence active component(s) other than alkaloids from methanolic extracts of curry leaves could be responsible for the observed anticancer effect against glioblastoma. In future, if phytoconstituents responsible for anticancer effect on glioblastoma cell line are identified and isolated it could lead to development of novel natural remedy against glioblastoma. Therefore, curry leaves appear to be a promising source of drug candidate for restricting the growth of glioblastoma cancer cells.

\section{REFERENCES}

1. Noda N, Wakasugi H. Cancer and oxidative stress. Jrnl of the Japan Med Asso. 2007;124(11):1571-4:1356-8650.

2. The Wealth of India: A Dictionary of Indian Raw Materials and Industrial Products. Publication and Information Directorate New Delhi: CSIR. 1998:446-8.

3. Prajapati ND, Purohit SS, Sharma AK, Kumar T. In; A and book of Medicinal Plants, $1^{\text {st }}$ Edn. Agrobios India. 2003, p.401.

4. Narasimhan NS, Paradkar MV, Chitguppi VP, Kelkar SL. Alkaloids of Murraya koenigii, Structures of mahanimbine, koenimbine, mahanine, koenine, koenigine and koenidine. Indian J Chem. 1975;13:993-5.

5. Rastogi RP, Mehrotra BN. In; Compendium of Indian Medicinal Plants, Volume 2, Central Drug Research Institute. Lucknow and National Institute of Science Communication, New Delhi.1980-1984;473-5.

6. Iyer D, Uma DP. Phyto-pharmacology of Murraya koenigii. Pharmacognosy Reviews. 2008;180-4.

7. Roy MK, Thalang VN, Trakoontivakorn G, Nkahara K. Mechanism of mahanineinduced apoptosis in human leukemia cells (HL-60). Biochem Pharmacol. 2004:67910:41.

8. Manfred F, John MP, Dajaja DS, Douglas AK. Phytochem. Nov. 1985;24(12):3041-3.

9. YihYihKok S, Lim YM, Kartini A, Mohd AS. Anti-Tumour Promoting Activity and Antioxidant Properties of Girinimbine Isolated from the Stem Bark of Murrayakoenigii. Molecules. 2012;17(4):4651-60.

10. Sanaye MM. Antistress activity of medicinal plant', PhD Thesis, submitted to SNDTWomen's University Mumbai, 2012

11. Blois MS. "Antioxidant determinations by the use of a stable free radical." Nat. 1958;181(4617):1199-200

12. Oyaizu M. Studies on products of browning reactions: antioxidant activities of products of browning reaction prepared from glucosamine. Japan Jrnl of Nutri. 1986;44:307-15

13. Ohkawa H, Ohishi N, Yagi K. Assay for Lipid Peroxides in Animal Tissues by Thiobarbituric Acid Reaction. Analyt biochem.1979;95(2):351-8.

14. Nishikimi M. Oxidation of ascorbic acid with superoxide anion generated by the xanthine-xanthine oxidase system. Biochem Biophy Res Comm. 1975 63(2):463-7.

15. Mandal P, Mishra T, Ghosal M. Free radical scavenging activity and phytochemical in the leaf and stem of Drymaria Diandra Blume. Int J Integr Biol. 7(2):80-4.

16. Skehn P, Storeng R, Scudiero A, Monks J, McMohan D, Vistica D. New colorimetric cytotoxicity assay for anticancer drug screening. J Natl Cancer Inst. 1990;82(13):1107.

17. Noolu B, Ajumeera R. Murraya koenigii extract inhibits proteasome activity and induces cell death in breast cancer cells. BMC Compl and Alter Med. 2013;13:1186-472.

\section{PICTORIAL ABSTRACT}

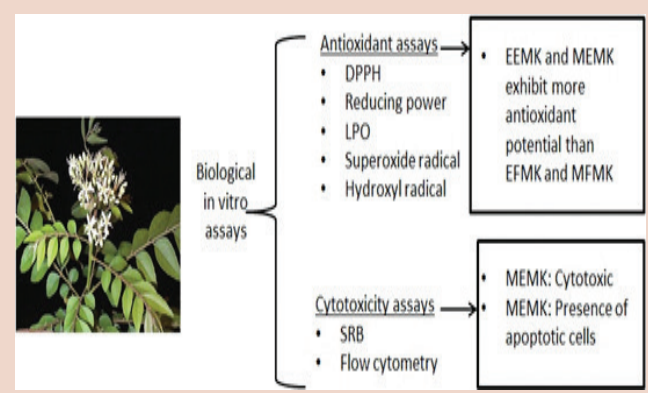

\section{SUMMARY}

- EEMK, MEMK, EFMK and MFMK presented good scavenging of DPPH free radical which might be due to their ability to transfer electrons to the DPPH radical thereby showing reduction in absorbance.

- In reducing power assay, the antioxidants in extracts and fractions brought about reduction of $\mathrm{Fe}^{3+}$ to $\mathrm{Fe}^{2+}$.

- Extracts and fractions exhibited a dose dependent increase in superoxide scavenging activity.

- In hydroxyl radical scavenging assay extracts were found to be more potent than fractions in scavenging hydroxyl radicals.

- In Flow cytometry analysis, apoptotic cells were found to be present after treatment with MEMK which were not observed on treatment with EEMK and fractions EFMK and MFMK.

\section{ABOUT AUTHORS}

Dr. Mrinal Sanaye is an Assistant Professor in the Department of Pharmacology at Principal K.M. Kundnani College of Pharmacy (Mumbai, India)). She has experience in the area of Pharmacology and Pharmacognosy of Natural Products, working mainly in: Neuropharmacology, Anticancer activity and cardiovascular studies of Natural products.

Nimisha Pagare is a post graduate student at Principal K.M. Kundnani College of Pharmacy (India). She graduated in Bachelor of Pharmacy. Her research focused on the evaluation of antioxidant activity and cytotoxicity of natural products. 